\title{
Phenotypic characters and identification CYPs (Cyclophilin) gene in Cucumis melo L. cv. Gama Melon Parfum
}

\author{
WIKO ARIF WIBOWO ${ }^{1}$, SIGIT DWI MARYANTO ${ }^{2,3, \vartheta}$, BUDI SETIADI DARYONO ${ }^{4, v \vee}$ \\ ${ }^{1}$ Graduate Program, Department of Tropical Biology, Faculty of Biology, Universitas Gadjah Mada. Jl. Teknika Selatan, Sekip Utara, Sleman 55281, \\ Yogyakarta, Indonesia \\ ${ }^{2}$ Faculty of Biology, Universitas Gadjah Mada. Jl. Teknika Selatan, Sekip Utara, Sleman 55281, Yogyakarta, Indonesia. \\ ${ }^{3}$ Biotechnology Department, Plant Production and Biotechnology Division, PT SMART Tbk. Jl. Raya Cijayanti, Babakan Madang, Bogor 16810, West \\ Java, Indonesia."email: sdmaryanto@yahoo.com \\ ${ }^{4}$ Laboratory of Genetics and Breeding, Department of Tropical Biology, Faculty of Biology, Universitas Gadjah Mada. Jl. Teknika Selatan, Sekip Utara, \\ Sleman 55281, Yogyakarta, Indonesia. Tel.: +62-274-580839, Fax.: +62-274-6492355, ••email: bs_daryono@mail.ugm.ac.id
}

Manuscript received: 15 December 2020. Revision accepted: 1 May 2021.

\begin{abstract}
Wibowo WA, Maryanto SD, Daryono BS. 2021. Phenotypic characters and identification CYPs (Cyclophilin) gene in Cucumis melo L. cv. Gama Melon Parfum. Biodiversitas 22: 3007-3014. Cucumis melo L. cv. Gama Melon Parfum is a new cultivar with a very strong fragrance as its main character. As a new cultivar with unique characters, it is necessary to characterize phenotype and molecular related to the fragrant aroma. The research aimed to study the phenotypic of the fruit of $C$. melo cv. Gama Melon Parfum $\left(\mathrm{F}_{3}\right)$ and to identify the CYPs gene as one of the genes that act in encoding volatile compounds. Analysis of qualitative characters was based on International Plant Genetic Resources Institute (IPGRI) and Plant Variety Protection (PVP), phenotypic characters in melons observed by abiding the Rules for Registration of Varieties from the Indonesian Minister of Agriculture Decree No. 700/Kpts/OT.320/D/12/2011, while analysis of quantitative characters was using the ANOVA methods and software PKBT-STAT-2. The methods of molecular characterization included RNA isolation, cDNA synthesis used Reverse Transcriptase-PCR, amplification of DNA target used PCR, visualization of DNA target used electrophoresis, and DNA sequencing. Analysis of the in silico approach was carried out on the CuGenDB Melon database. Analysis of protein sequences and classification was obtained from InterPro. Phylogeny analysis using MEGA-X Software. The results were 18 qualitative characters and 11 quantitative characters were stable and uniform, whereas the molecular characterization of the genes was predicted Cyclophilin with peptidylprolyl isomerase (PPIase) activity and located in chromosome 1 (17059021-17058899).
\end{abstract}

Keywords: Cyclophilin gene, Gama Melon Parfum, morphology, PPIase, volatile compound

\section{INTRODUCTION}

Melon is a crop with high economic value. Many efforts were made to develop superior cultivars of these plants through plant breeding to increase the sale value in the community (Daryono et al. 2019). According to Munger and Robinson (1991), melons can be classified into several groups based on morphotypes, particularly vegetative morphology and fruit variations. The group includes Agrestis (Africa), Flexuosus (snake melon; Middle East), Conomon (Asia), Cantaloupensis (Middle East), Inodorus (Middle East, Southern Europe), Chito (mango melon; Asia), Dudaim (Queen's pocket melon; Asia), and Momordica (Phoot or snap melon: Asia) (Whitaker and Bemis 1976; Rubatzky and Yamaguchi 1997; Robinson and Decker-Walters 1997). The melon groups commonly cultivated in Indonesia are Cantaloupensis and Inodorus (Daryono and Maryanto 2017). In line with their high economic value and diversity, melons are widely used as research models that include genome mapping through whole-genome shotgun sequencing (Garcia-mas et al. 2012; Ruggieri et al. 2018). The unique characteristics of each melon cultivar are appealing to be studied its morphology and molecular characterization of new melon cultivars resulted from breeding.

Gama Melon Parfum (GMP) cultivation was carried out in 2011 by crossing ㅇ NO3 and $\sigma^{\Uparrow}$ MR5 broodstock and produce a unique cultivar with a very strong fragrance and bitter taste of the flesh fruit (not edible) so that it has the potential to be used as a raw material for cosmetics industry (Maryanto et al. 2014). GMP melons have similar characteristics with Duda'im melons (Duda'im Group), also known as Queen Anne's Pocket Melons with its special characters of small, spherical, thin-fleshed, insipid, dark-orange with brown-yellow striped ripe fruits, and fragrance (Paris et al. 2012). The distinguishing characters in GMP melons are turbine structure at the tip of the fruit, bitter taste in the flesh, and differences in the shape of the longitudinal pattern (Daryono and Maryanto 2017).

The first generation GMP melons $\left(F_{1}\right)$ had a harvest period of 63-65 days after planting with stable phenotypic characters (Maryanto et al. 2014), however in the $F_{2}$ had found segregation. The intergenerational stability of GMP melons is needed to ensure the cultivation program success, particularly the phenotype stability which refers to the genotype that is able to display phenotypes stably without being influenced by different environmental conditions 
(Breseghello and Coelho 2013). Phenotype stability can be assessed from the morphological characters that include observations of the qualitative and quantitative phenotypic characters of the fruit (Bagheriyan et al. 2015).

Molecular characterization was carried out on the types of genes that affect the expression of fruit volatile compounds as the main and unique character of GMP melons. The sweet aroma of melons is produced from volatile compounds from the terpenoids, esters, alcohols, and aldehydes (Shalit et al. 2001; Schwab et al. 2008; Hasbullah et al. 2019). Terpenoids are a group of secondary metabolites that contain isoprene groups $\left(\mathrm{C}_{5}\right)_{n}$ (Degenhardt et al. 2009). The hemiterpenes $\left(\mathrm{C}_{5}\right)$ and monoterpenes $\left(\mathrm{C}_{10}\right)$ are usually volatile due to the small size of the compounds, while the diterpenes $\left(\mathrm{C}_{20}\right)$ can be aromatic from the side chains containing phenylalanine (Dewick 2002). Cyclophilins are one of the proteins that function in forming the ring structure of diterpenes in rice plants (Wang et al. 2012; Acevedo et al. 2019; Yu et al. 2019). Cyclophilins are encoded by the CYPs gene, it has wide function, diverse, and highly conserved (Barbosa dos Santos and Park 2019). Cyclophilins belongs to large family of proteins called immunophilins and generally has peptydil prolyl cis-trans isomerase (PPIase) or rotamase activity (Kumari et al. 2013).

Therefore, GMP melons as a new cultivar with a unique character of a fragrant aroma needs to be characterized morphologically to observe phenotypic stabilization in the $\mathrm{F}_{3}$ and molecular generations based on the fragrant aroma as one of the special characteristics of GMP melons. This study aims to analyze the phenotypic characters of GMP $\left(F_{3}\right)$ and its molecular character through the identification of CYPs genes as one of the genes that influence the expression of GMP cultivar volatile compounds.

\section{MATERIALS AND METHODS}

\section{Plant and cultivation materials}

GMP melons planting was carried out at the Greenhouse of PIAT (Pusat Inovasi Agroteknologi) University of Gadjah Mada in Kalitirto, Berbah, Sleman, Yogyakarta in February-April 2019. The GMP seeds used are $F_{3}$ obtained through the rigorous selection from the $F_{2}$ generation. The germinated GMP seeds are then planted into a polybag containing planting media. After the age of 7 days, it was planted in beds that have been shaped and given mulch and bamboo equipped with a spacing of 50 $\mathrm{cm}$. During growth, adequate fertilizer, irrigation, and treatment are provided. During the growth, the lateral branch of the melon plant is also carried out to optimize its growth. In one melon plant, 8-10 fruits are chosen to be raised. Melons are harvested at the age of 63-65 days after cultivation (DAC) (Daryono et al. 2019).

\section{Sampling and observation of morphological characters}

The research was laid out in a Complete Randomized Block Design (RCBD) with a total of 40 plants of GMP (Gomez and Gomez 2007). Variables observed were phenotypic characters consisting of qualitative phenotypic characters in melons observed based on the International Plant Genetic Resources Institute (IPGRI) and Plant Variety Protection (PVP) including fruit shape, immature fruit skin color, mature fruit skin color, net score, skin surface color pattern, longitude line, the presence of lobes, number of lobes, turbine, turbine shape, longitudinal cut cavity shape, transversely cut cavity shape, flesh color, fruit flesh texture, moisture content, taste, aroma, seed color. The quantitative phenotype characters in melons observed by abiding the Rules for Registration of Varieties from the Indonesian Minister of Agriculture Decree No. 700/Kpts/OT.320/D/12/2011, includes fruit weight, fruit circumference, base diameter of the fruit, tip diameter of the fruit (turbine), horizontal diameter, vertical diameter, fruit skin thickness, fruit flesh thickness, number of seeds, the weight of 100 seeds.

\section{Molecular characterization}

The methods used for molecular characterization include RNA isolation using GeneJet Fermentas ThermoFisher Scientific. The stages of RNA isolation include mechanical skin scouring and chemical cell coating, RNA removal of other cell components or debris, and RNA precipitation. RNA molecules that have been obtained are converted into cDNA through a reverse transcription process. The cDNA synthesis with RT-PCR according to the instruction kit used (Thermo Scientific RevertAid First Strand cDNA Synthesis Kit, Fermentas) and optimization at $42^{\circ} \mathrm{C}$ for 1 hour followed by termination at $70^{\circ} \mathrm{C}$ for 5 minutes. In the two-step PCR technique, the random primary is used to obtain cDNA from the whole melon genome transcript product so that the PCR reaction can be done with various primers (Van Pelt-Verkuil et al. 2008). The cDNA products obtained were then amplified with specific primers to detect genes involved in the synthesis of volatile compounds as a characteristic of GMP melons. The DNA target amplification by PCR using the Mega Mix Blue (MMB) kit and forward primer 5'GATGGAGCTCTACGCCGATGTC-3' and reverse 5'CCTCCCTGGCACATGAAATTAG-3' (Portnoy et al. 2008). The optimization measured by pre-denaturation at a temperature of $94^{\circ} \mathrm{C}$ for 3 minutes, followed by 35 times the PCR cycle, including denaturation $\left(94^{\circ} \mathrm{C}\right.$ for 30 seconds), annealing $\left(58^{\circ} \mathrm{C}\right.$ for 30 seconds) and extension $\left(72^{\circ} \mathrm{C}\right.$ for 45 seconds), then the final extension for 10 minutes at $72^{\circ} \mathrm{C}$ and the reaction is stopped at $4^{\circ} \mathrm{C}$, target DNA visualization by electrophoresis. The target DNA sequences obtained using the Sanger method. Reference CYPs genes are taken from the National Center for Biotechnology Information (https://www.ncbi.nlm.nih.gov/) including the species Cucumis melo (XM_008449764.1) Cucurbita pepo (XM_023697952.1 and XM_023674034.1), C. moschata (XM_023096708.1 and XM_023072675.1), C. maxima (XM_023133298.1), C. Sativus (NM_001280769.1), Lactuca sativa (XM_023880581.1 and XM_023875690.1), Ipomea nil (XM_019298926.1), and Camelina sativa (XM_010448089.2 and XM_010433520.2). 


\section{Data analysis}

Morphological character analysis was carried out qualitatively and quantitatively. Quantitative characters are analyzed using PKBT-STAT-2 software. (Maryanto et al. 2014). The sequencing results were analyzed using GeneStudio software. The nucleotide base sequences obtained were aligned using BLAST. Analysis of the in silico approach was carried out on the CuGenDB Melon database (DHL92) v3.6.1 genome (http://cucurbitgenomics.org/). Analysis of protein sequences and classifications was obtained from InterPro (https://www.ebi.ac.uk/interpro/). Phylogeny analysis using MEGA-X Software with Kimura-2 algorithm parameter neighbor-joining approach and bootstrap 1000 (Kimura 1980; Saitou and Nei 1987; Srivathsan and Meier 2012).

\section{RESULTS AND DISCUSSION}

\section{Morphological characters}

Observation of qualitative phenotypic characters obtained were oblate fruit shape, small size, yellow-orange fruit skin color with 6-10 lobes, white fruit flesh color, crunchy texture, bitter taste, net score 0 (no netted melon), and has a specific character in the apical part called a turbine. The turbin structure can emerge from the development of the ovaries. The development of fruit by cell division during the crucial phase, that is, before and after flower anthesis, especially from the flowers organ that is the tissue development in the pistil (Avalos et al. 2019; Yang et al. 2019). The turbine structure resembles a bulge found at the fruit apical and it is thought that it was originated from the stigma remnants after pollination process and still drags during plant growth (Figures 1 and 2). Observations details of the qualitative phenotype characters are presented in Table 1.

The quantitative phenotypic character was obtained from the average measurement results of GMP fruit samples (Table 2). The character of GMP fruit is unique because it is small in size and can be found 6-8 fruits in one plant with a harvest period of 63-65 DAC.

The overall phenotype character of GMP is used as the basis for registering GMP as a new cultivator to the Indonesian Ministry of Agriculture and has obtained a certificate of registration in 2017.
The results of statistical analysis to determine the stability and uniformity of quantitative phenotype characters are shown in Table 3.

Table 1. Qualitative phenotype character of cultivar Gama Melon Parfum

\begin{tabular}{|c|c|c|}
\hline $\begin{array}{l}\text { Qualitative phenotype } \\
\text { character }\end{array}$ & $\begin{array}{l}\text { Gama Melon } \\
\text { Parfum (GMP) }\end{array}$ & $\operatorname{GMP}\left(\mathbf{F}_{1}\right)$ \\
\hline Fruit shape & Oblate & Oblate \\
\hline Immature fruit skin color & Green & * \\
\hline Mature fruit skin color & Brownish green & Brownish green \\
\hline Net score & 0 & $*$ \\
\hline Skin surface color pattern & $\begin{array}{l}\text { Longitudinal } \\
\text { with 'batik' } \\
\text { pattern }\end{array}$ & * \\
\hline Longitude line & $6-10$ & $9-10$ \\
\hline The presence of lobes & Presence & * \\
\hline Number of lobes & $6-10$ & $9-10$ \\
\hline Turbin & Presence & Presence \\
\hline Turbin shape & 1/8-1/2 circle & * \\
\hline Longitudinal cut cavity shape & Pear & $*$ \\
\hline Transversely cut cavity shape & Circle & $*$ \\
\hline Flesh color & White & White \\
\hline Fruit flesh texture & Crunchy & Crunchy \\
\hline Moisture content & Little & $*$ \\
\hline Taste & Bitter & Bitter \\
\hline Aroma & Very fragnant & Very fragnant \\
\hline Seed color & White & \\
\hline
\end{tabular}

Table 2. Quantitative phenotype characters of cultivar Gama Melon Parfum

\begin{tabular}{lrr}
\hline $\begin{array}{l}\text { Quantitative phenotype } \\
\text { character }\end{array}$ & \multicolumn{1}{c}{$\begin{array}{c}\text { Results } \\
\text { (average) }\end{array}$} & GMP $\left(\mathbf{F}_{\mathbf{1}}\right)$ \\
\hline Fruit weight $(\mathrm{g})$ & $118.50 \pm 29.425$ & 160 \\
Fruit circumference (cm) & $19.99 \pm 1.88$ & 21.8 \\
Horizontal diameter (cm) & $6.32 \pm 0.54$ & 6.89 \\
Vertical diameter (cm) & $6.30 \pm 0.54$ & 6.44 \\
Fruit skin thickness (cm) & $0.22 \pm 0.06$ & 0.1 \\
Fruit flesh thickness (cm) & $1.08 \pm 0.21$ & 1.06 \\
Number of seeds (grain) & $244.85 \pm 94.01$ & $200-300$ \\
Weight of 100 seeds (g) & $1.52 \pm 0.36$ & 1.74 \\
\hline
\end{tabular}
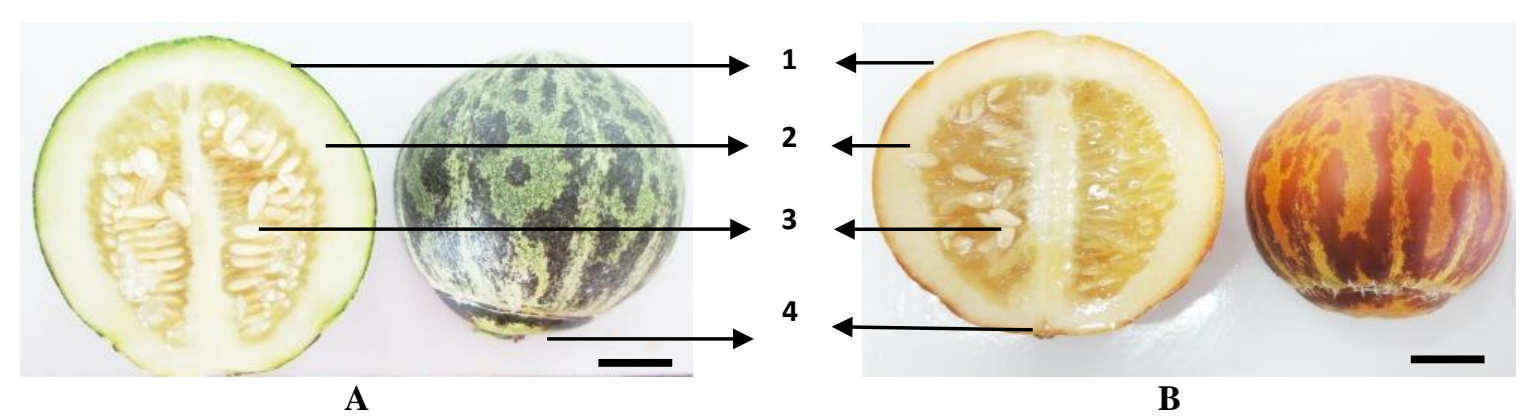

Figure 1. Cultivar Gama Melon Parfum after cut longitudinally. Note: A. Immature: 20 Day After Anthesize (DAA); B. Mature: 35 DAA. 1. Skin (epidermis); 2. Fruit flesh (mesoderm); 3. Seed placenta (endodermis); 4 . Turbine structure. Bar $=2 \mathrm{~cm}$ 

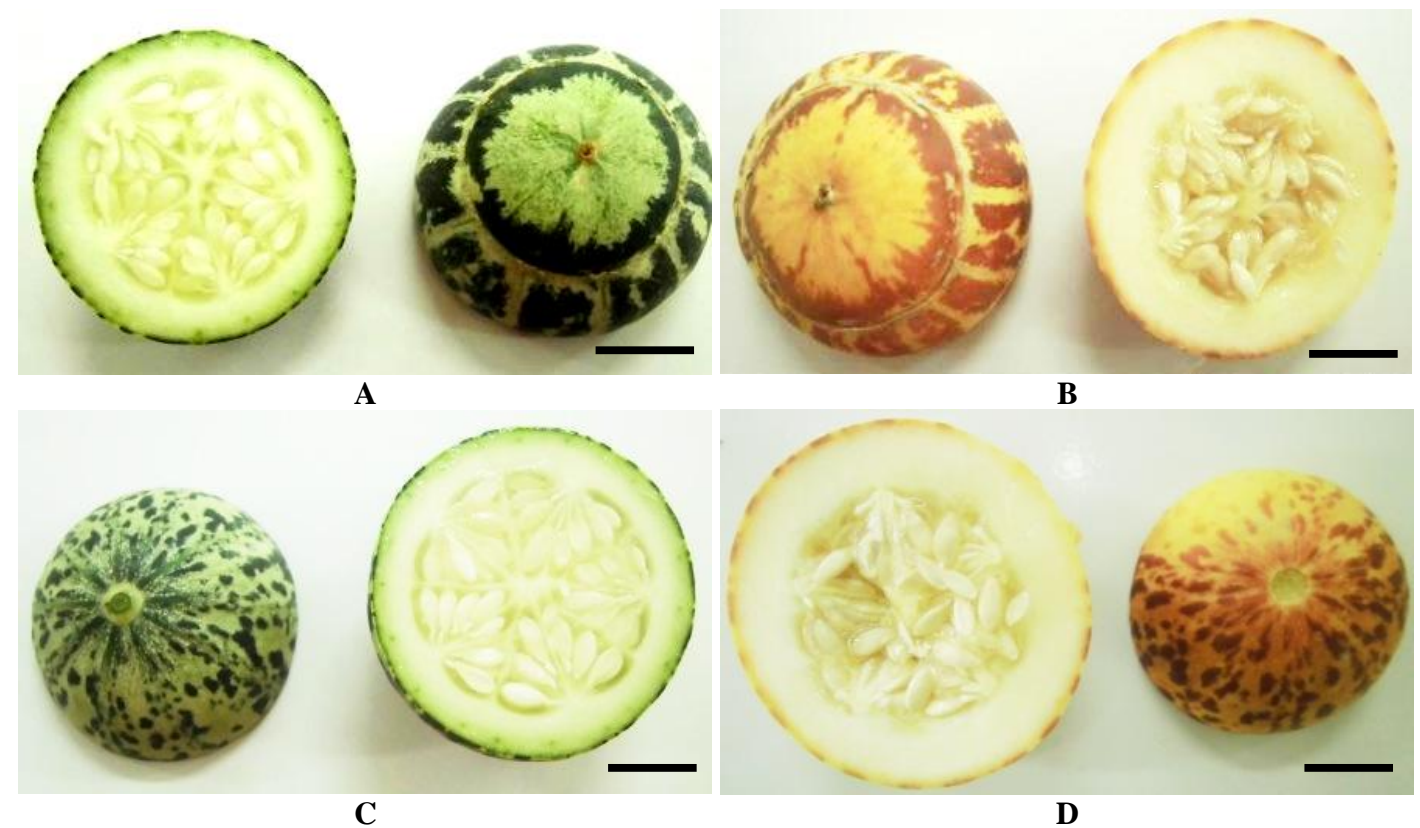

Figure 2. Cultivar Gama Melon Parfum after cut transversally; A. Cross-section view with apical (immature: 20 DAA); B. cross-section view with apical (mature: 35 DAA); C. Cross-view with base (immature); D. Cross-view with base (mature). Bar $=2 \mathrm{~cm}$

Table 3. Summary of statistical analysis

\begin{tabular}{lcc}
\hline Characters & Sig. & CV (\%) \\
\hline Fruit weight & ns & 32.77 \\
Fruit circumference & ns & 12.46 \\
Horizontal diameter & ns & 10.52 \\
Vertical diameter & ns & 10.62 \\
Fruit skin thickness & ns & 24.10 \\
Fruit flesh thickness & ns & 24.48 \\
Turbin & ns & 29.88 \\
Weight of 100 seeds & ns & 30.14 \\
\hline
\end{tabular}

Note: ns: not significant

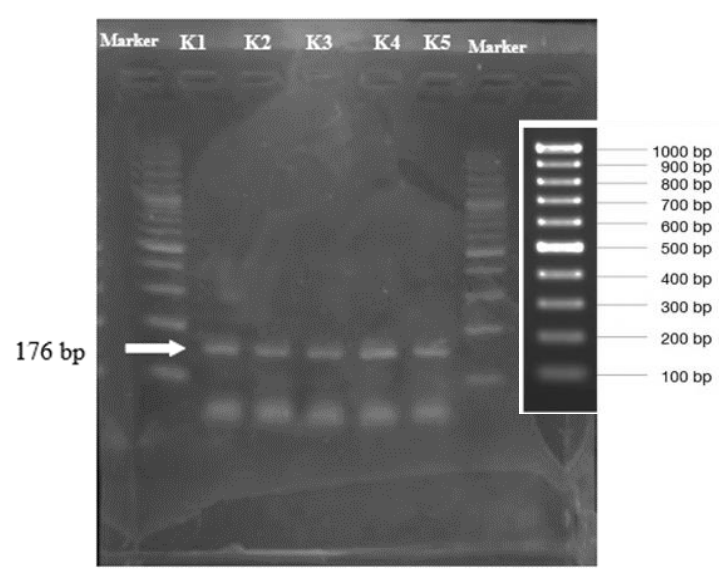

Figure 3. The DNA fragment of gene encoding of volatile compounds in Cucumis melo cv. Gama Melon Perfum with a length of $176 \mathrm{bp}$ in the sample weeks 1 to 5 (K1-K5: fruit skin 1st to 5 th week)
Based on Table 3, it is known that the interaction between replicates was not significantly different. This suggest that the characters observed in the GMP $\mathrm{F}_{3}$ population are stable and uniform. The Coefficient of Variation $(\mathrm{CV})$ value obtained is less than $50 \%$ for all characters so that the distribution of quantitative morphological character data is normally distributed.

\section{Molecular characters}

Molecular characterization begins with the isolation of total RNA against the skin of GMP melons in 5 samples aged from 1st week to 5th week after bloom (DAA). The positive DNA results are presented in Figure 3. We selected one DNA band to be sequenced. The size of the DNA band obtained was $176 \mathrm{bp}$ and after analyzing the sequencing results obtained 123 bp which could be continued for further analysis. There is a difference in the number of nucleotide bases obtained after analysis due to the trimming process at the beginning and end of the sequence to obtain a good quality sequence and avoid ambiguous bases.

\section{Identification and localization of CYP gene}

The nucleotide bases from the fragments obtained are then aligned to identify the type of gene. The alignment was carried out specifically on the Cucumis melo genome database (Melon (DHL92) v3.6.1). 123 nucleotide bases were positively identified with a $100 \%$ compatibility rate on chromosome number 1 at position 17058899-17059021 (Figure 4).

After further identification, the position was entered into the CYPs gene or also known as Peptidyl-prolyl cistrans isomerase (PPIase) with complete ID gene identification MELO3C013375.2 (Table 4). 


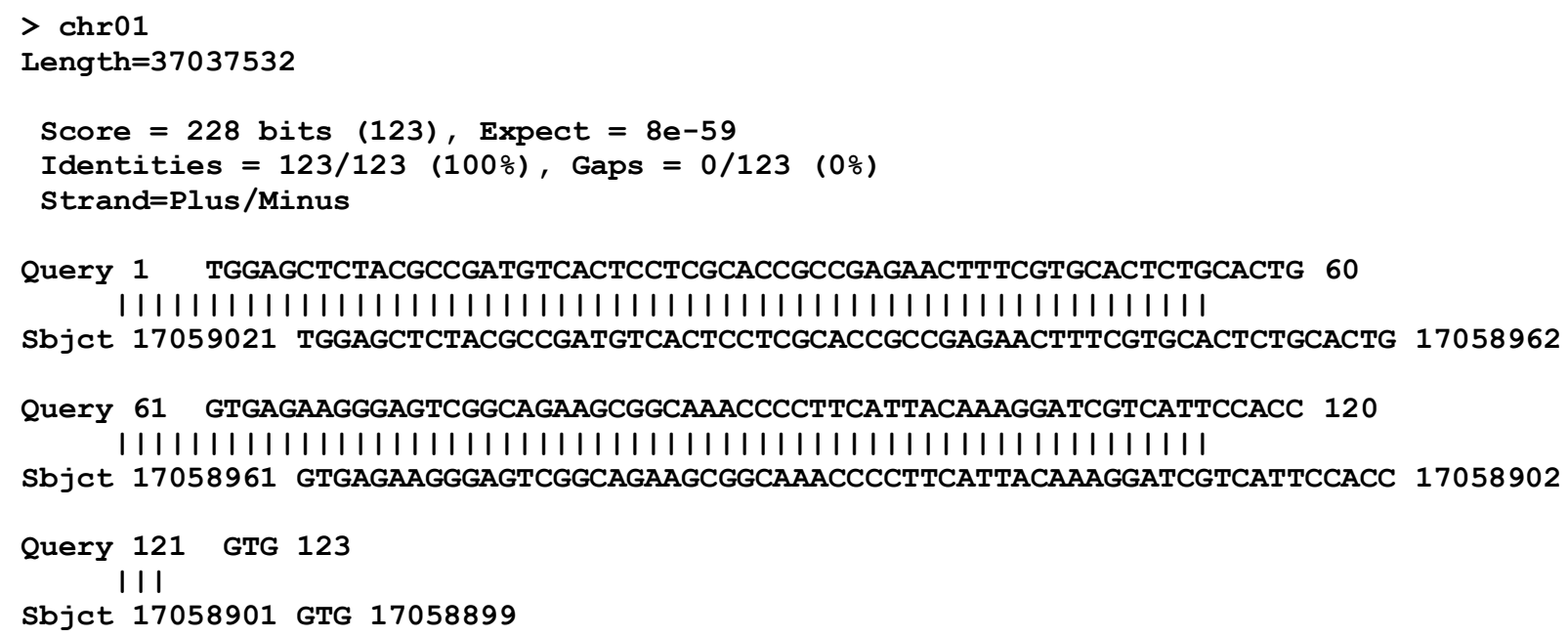

Figure 4. Characterization and localization of genes that have been identified

Table 4. Information on MELO3C013375.2 gene data

\begin{tabular}{ll}
\hline MELO3C013375.2 & (gene) Melon (DHL92) v3.6.1 \\
\hline Name & MELO3C013375.2 \\
Type & Gene \\
Organism & Cucumis melo (Melon (DHL92) v3.6.1) \\
Description & Peptidyl-prolyl cis-trans isomerase \\
Location & Chr01: 17058214-17059161 \\
\hline
\end{tabular}

The nucleotide base obtained is a fragment of the MELO3C013375.2 gene but does not constitute the whole gene, because the primary construction used is not able to encompass the whole gene which has a length of $948 \mathrm{bp}$. The sequencing results analysis process also reduced the amount of DNA base size obtained to only 123 nucleotide bases, but the $100 \%$ similarity and the absence of other results showing the similarity of the sequences made us confident that one of the genes that influence the activity of volatile compounds in GMP fruit was this gene.

\section{Phylogeny and genetic distance}

The results of the phylogeny tree construction are shown in Figure 5. The results show that the PPIase coding gene contained in GMP melons has a high similarity value with the PPIase coding gene in melon ( $C$. melo) locus 103490307 with genetic distance is 0.00 and is closely related to genes in the $C$. sativus locus 101206458 (Figure 4) with value i.e. 0.0507 .

In general, partial CYPs gene fragments from GMP melons are evolved into cladding $\mathrm{I}$ in the form of Cucurbitaceae plant groups, namely $C$. sativus, Cucurbita moschata, Cucurbita pepo, and Cucurbita maxima, and are separated from the second clade with members of Lactuca sativa (Asteraceae) and third clade Camelina sativa (Brassicaceae), and Ipomoea nil (Convolvulaceae).

\section{Discussion}

The morphological character of GMP shows stable results both in the $F_{3}$ population and when compared to the previous generation $\left(\mathrm{F}_{1}\right)$ that was registered with the Ministry of Agriculture under number 508/PVHP/2017. Measurement of morphological characters was carried out using qualitative phenotypes and quantitative phenotypes. Maryanto et al. (2014) have succeeded in characterizing GMP for the first time from the results of crossing NO3 and MR5. There are some minor differences in quantitative fruit size based on variety registration data (PVHP 2017) and crossover characterization data (Maryanto et al. 2014) which are still acceptable in the phenotype spectrum variations. The differences that are known to be due to quantitative characters are controlled by several genes and are influenced by interactions, the main characteristic of GMP which is measured from the qualitative character is the turbine structure which is the rest of the pistil and is located at the bottom of the fruit (Isnaini 2016); fruit skin color pattern that resembles batik; and very strong scents were stably expressed in each generation and in individuals in the $F_{3}$ population. Turbines are a special character that is very rarely found in Cucumis melo. Turbine structures are common in the Cucurbita maxima variety Turk's Turban (Agbagwa and Ndukwu 2004). Based Isnaini (2016), the turbine network is composed of cells from the basal stigma attached to the apical mesocarpal tissue. Meanwhile, the character of the very fragrant aroma of GMP fruit is influenced by the 3-penten-2-ol, hexyl acetate, and 3hydroxy 2-butanone compounds (Hasbullah et al. 2019). 


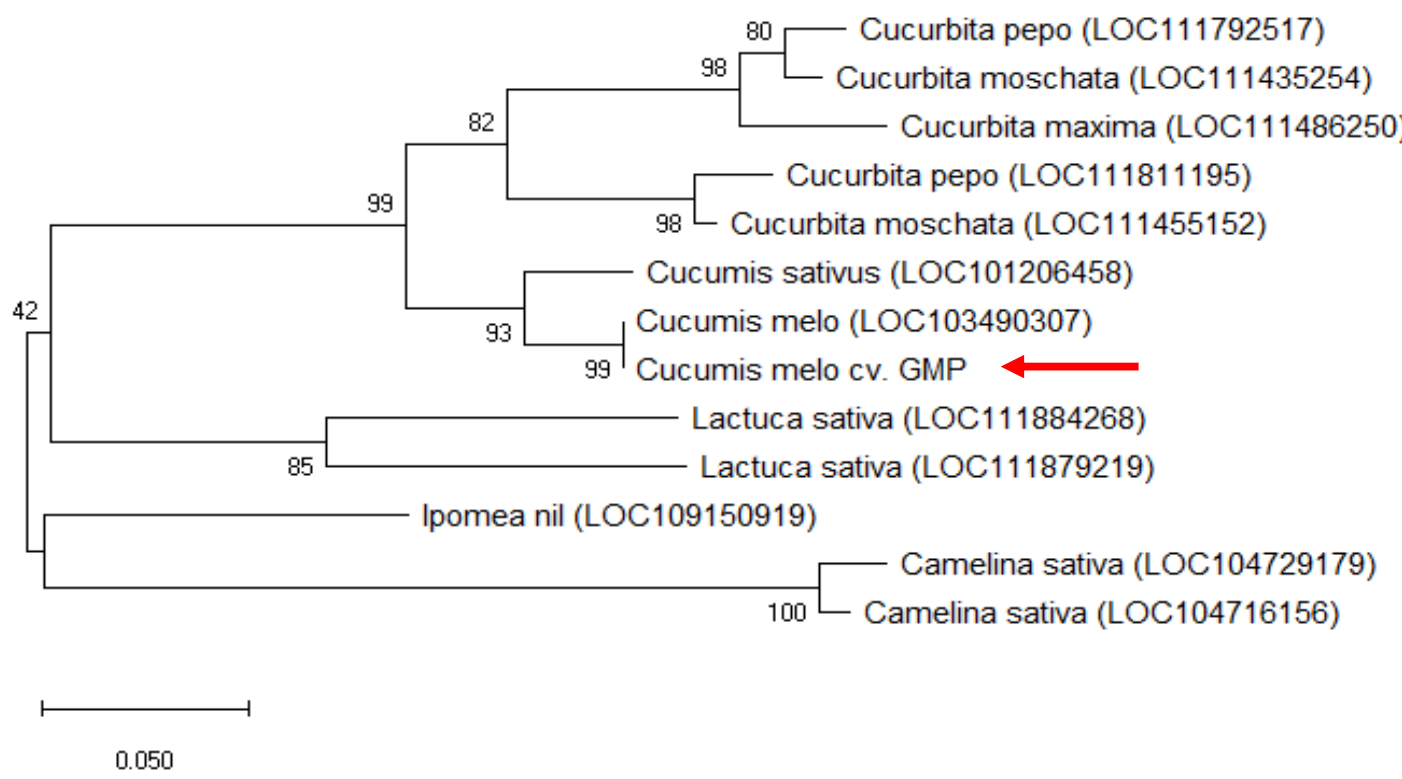

Figure 5. Phylogenetic tree of CYP gene Cucumis melo cv. Gama Melon Parfum with various plants, bootstrap 1000

The fragrant aroma found in the GMP melons are thought to originate from the rind. RNA isolation was carried out to obtain gene sequences that were transposed on the structure of GMP's rind. GMP fruit samples were taken from the first week to the fifth week to observe the timing of aroma gene expression (Figure 3). cDNA amplification was carried out with primary cyclophilins as a housekeeping gene that contributes to the synthesis of terpene compounds (Portnoy et al. 2008). The number of nucleotide bases is reduced due to the process of cutting the ambiguous base at the beginning and end of the sequence (5 'and 3' ends) as a part of initially assembled and inspected visually fo reading errors (Arisuryanti et al. 2019).

Through the in-silico approach in the melon genome database, we have identified that the gene is MELO3C013375.2 (Table 3). Based on database information it is known that it has functions that have been associated with this gene, namely protein folding and protein peptidyl-prolyl isomerization for biological processes and peptidyl-prolyl cis-trans isomerase (PPIase) activity for molecular functions (Zheng et al. 2018). Then when referring to the in silico approach through protein sequence analysis and classification (InterPro) this gene is related to Cyclophilins type PPIase (Fischer and Schmidt 1990; Stamnes et al. 1992; Wang and Hitman 2005).

CYPs found in the skin of the GMP melon inferred to associate with the synthesis of volatile compounds and changes in the colour of the fruit peels during the ripening process. Cyclophilin is one of the largest enzyme families that support metabolic processes in plants which have essential functions in light-harvesting (carotenoids) and hormone biosynthesis (Nelson and Werck-Reichhart 2011). CYPs can be found in all prokaryotes and eukaryotes because they have a conserved structure in the evolutionary process and play an important role in cellular functions (Barbosa dos Santos and Park 2019). Besides, they show that there are 109 common amino acids as Cyclophilin-like domain (CLD) which have PPIase activity which will be added to specific domains for each type that play an important role in the selection of protein substrates and subcellular compartmentation (Nagy et al. 2011).

Specifically, CYPs are involved in various processes including protein exchange and maturation, receptor stabilization complexes, apoptosis, receptor signaling, RNA formation, and spliceosome assembly (Kumari et al. 2013). In rice plants (O. sativa), CYPs play a role in the formation of the hormone gibberellin (GA). The formation of GA originates from pre-GA which will be catalyzed by terpene synthase. CYPs will play a role in the formation of a ring which in turn will form the hormone gibberellin (Wang et al. 2012). Meanwhile, Hasbullah et al. (2019) and Esteras et al. (2018) stated that the groups of terpene compounds detected in melons are sesquiterpene and monoterpene. This indicates the role of CYPs specifically in the metabolic system of melon plants against these compounds which are different from those of rice plants.

Based on the PPIase gene coding for the enzyme PPIase, the phylogeny analysis obtained validated that GMP was a breeding variety of Cucumis melo (Figure 5). In addition, melons have a close relationship with cucumbers compared to other members of the Cucurbitaceae. According to Chung et al. (2006), melons are sister of cucumbers based on consensus chloroplast simple sequence repeat (ccSSR). Meanwhile Renner et al. (2007) revealed an indication of the deepest divergence in Cucumis is between C. sativus and C. melo. Although there is much contentions over the phylogenetic relationship within the Cucumis group due to the very high level of species diversity, the PPIase gene of C. melo 
(MELO3C013375.2) is orthologous with C. sativus, included C. pepo and C. maxima (Garcia-Mas et al. 2012; Ruggieri et al. 2018; Zheng et al. 2018;). It is also suspected to be orthologous with $C$. moschata but this species does not yet have any information in the database. This proves that GMP as part of the Cucumis melo has a common ancestor with members of the Cucurbitaceae. The orthology nature of the PPIase gene also indicates that this gene has the same function in different species as a result of the speciation process (Moreira 2014).

To conclude, GMP $\left(\mathrm{F}_{3}\right)$ has a stable morphological character while maintaining the key characters in the form of turbine structure and fragrant aroma of fruit. The CYPs gene was identified with the code MELO3C013375.2 which encodes PPIases and is orthology at the family level (Cucurbitaceae). CYPS gene is inferred as one of that influence the biosyhnthesis of volatile compound towards express the fragrant aroma of fruit, however it is necessary to further analysis the difference in the level of $C Y P S$ gene expression in melons.

\section{ACKNOWLEDGEMENTS}

This research was supported by the Ministry of Technology Research and Higher Education of the Republic of Indonesia through PMDSU Grants through contract number 2936/UN1.DITLIT/DIT-LIT/LT/2019.

\section{REFERENCES}

Acevedo LA, Kwon J, Nicholson LK. 2019. Quantification of reaction cycle parameters for an essential molecular switch in an auxin responsive transcription circuit in rice. Proc Natl Acad Sci USA 116 (7): 2589-2594. DOI: 10.1073/pnas.1817038116.

Agbagwa IO, Ndukwu BC. 2004. The value of morpho-anatomical features $\mathrm{n}$ the systematics of Cucurbita L. (Cucurbitaceae) species in Nigeria. Afr J Biotechnol 3 (10): 541-546. DOI: 10.5897/AJB2004.0002106.

Arisuryanti T, Pratama GA, Hakim L, Koentjana JP, Nazira FK. 2019. Genetic characterization of kissing gourami (Helostoma temminckil Cuvier, 1829) in ogan river, south sumatera inferred from $16 S \mathrm{rRNA}$ and COI mitochondrial genes. Indon Fish Res J 25 (1): 37-44. DOI: 10.15578/ifrj.25.1.2019.37-44

Avalos AA, Zini LM, Ferrucci MS, Lattar EC. 2019. Anther and gynoecium structure and development of male and female gametophytes of Koelreuteraia elegans subsp. formosana (Sapindaceae): Phylogenetic implications. Flora: Morph Distrib Funct Ecol Plants 255: 98-109. DOI: 10.1016/j.flora.2019.04.003.

Bagheriyan S, Karimi HR, Esmaelizadeh M. 2015. Evaluation of genetic relationships among melon genotypes based on morphological markers. Intl J Vegetable Sci 21 (1): 36-52. DOI: 10.1080/19315260.2013.818608.

Barbosa dos Santos I, Park SW. 2019. Versatility of cyclophilins in plan growth and survival: A case study in Arabidopsis. Biomolecules 9 (1): 20. DOI: $10.3390 /$ biom 9010020

Breseghello F, Coelho ASG. 2013. Traditional and modern plant breeding methods with examples in rice (Oryza sativa L.). J Agric Food Chem 61: 8277-8286. DOI: 10.1021/jf305531j.

Chung SM, Staub JE, Chen JF. 2006. Molecular phylogeny of Cucumis species as revealed by consensus chloroplast SSR marker length and sequence variation. Genome 49 (3): 219-229. DOI: 10.1139/g05-101.

Daryono BS, Maryanto SD. 2017. Diversity and Potential Genetic Resources of Melons. Gadjah Mada University Press, Yogyakarta. [Indonesian]
Daryono BS, Subiastuti AS, Fatmadanni A, Sartika D. 2019. Phenotypic and genetic stability of new Indonesian melon cultivar (Cucumis melo L. "Melonia") based on ISSR markers. Biodiversitas 20 (4): 10691075. DOI: 10.13057/biodiv/d200419.

Degenhardt J, Köllner TG, Gershenzon J. 2009. Phytochemistry monoterpene and sesquiterpene synthases and the origin of terpene skeletal diversity in plants. Phytochemistry 70 (15-16): 1621-1637. DOI: 10.1016/j.phytochem.2009.07.030.

Dewick PM. 2002. Medicinal Natural Product: A Biosynthetic Approach, second ed. John Wiley \& Sons, Inc., Chicester.

Esteras C, Rambla JL, Sanchez G, Lopez-Gresa MP, Gonzalez-Mas MC, Fernandez-Trujillo JP, Belles JM, Granell A, Pico MB. 2018. Fruit flesh volatile and carotenoid profile analysis within the Cucumis melo L. species reveals unexploited variability for future genetic breeding. J Sci Food Agric 98 (10): 3915-3925. DOI: 10.1002/jsfa.8909.

Fischer G, Schmidt FX. 1990. The mechanism of protein folding. Implications of in vitro refolding models for de novo protein folding and translocation in the cell. Biochemistry 29 (9): 2205-2212. DOI: 10.1021/bi00461a001.

Garcia-mas J, Benjak A, Sanseverino W, Bourgeois M, Mir G, Gonzalez VM, Henaff E, Camara F, Cozzuto L, Lowy E, Alioto T, CapellaGuitierrez S, Blanca J, Canizares J, Ziarsolo P, Gonzalez-Ibeas D, Rodriguez-Moreno L, Droege M, Du L, Alvarez-Tejado M, LorenteGaldos B, Mele M, Yang L, Weng Y, Navarro A, Marques-Bonet T, Aranda MA, Nuez F, Pico B, Gabaldon T, Roma G, Guigo R, Casacuberta JM, Arus P, Puigdomenech P. 2012. The genome of melon (Cucumis melo L.). Proc Natl Acad Sci USA 109: 1187211877. DOI: 10.1073/pnas.1205415109.

Gomez KA, Gomez AA. 2007. Statistical Procedures for Agricultural Research. I-Press, Jakarta. [Indonesian]

Hasbullah UHA, Supriyadi, Daryono BS. 2019. Aroma volatile compounds profile of melon (Cucumis melo L.) cv. Gama Melon Parfum. IOP Conf Ser Earth Environ Sci 292: 012027. DOI: 10.1088/1755-1315/292/1/012027.

International Plant Genetic Resources Institute. 2003. Descriptor for melon (Cucumis melo L.). International Plant Genetic Resources Institute, Rome.

Isnaini L. 2016. Anatomical Structure and Turbinate Development of Melon (Cucumis melo L. 'Hikadi Aromatik'). [Thesis]. Universitas Gadjah Mada, Yogyakarta. [Indonesian]

Kimura M. 1980. A simple method for estimating evolutionary rates of base substitutions through comparative studies of nucleotide sequences. J Mol Evol 16 (2): 111-120. DOI: 10.1007/BF01731581.

Kumari S, Roy S, Singh P, Singla-Pareek S, Pareek A. 2013. Cyclophilins: Proteins in search of function. J Plant Signal Behav 8 (1): 25-32. DOI: $10.4161 / \mathrm{psb} .22734$

Maryanto SD, Ranis RE, Daryono BS. 2014. Stability phenotypic characters and the scent of gama melon perfume cultivar. IPTEK J Proc Ser 1 (1): 523-528

Moreira D. 2014. Orthologous gene. In: Amils R, Quintanilla J, Gargaud M. (eds) Encyclopedia of Astrobiology. Springer, Berlin.

Munger HM, Robinson RW. 1991. Nomenclature of Cucumis melo L. Cucurbit Genet Coop Rep 14: 43-44.

Nagy PD, Wang RY, Pogany J, Harfen A, Makinen K. 2011. The dependence of viral RNA replication on co-opted host factors. Nat Rev Microb 10 (2): 137-149. DOI: 10.1038/nrmicro2692.

Nelson D, Erck-Reichhart D. 2011. A P450-centric view of plant evolution. Plant J 66 (1): 194-211. DOI: 10.1111/j.1365313X.2011.04529.x.

Paris HS, Amar Z, Lev E. 2012. Medieval emergence of sweet melons, Cucumis melo (Cucurbitaceae). Ann Bot 110 (1): 23-33. DOI: 10.1093/aob/mcs098.

Portnoy V, Benyamini Y, Bar E, Harel-Beja R, Gepstein S, Giovanni JJ, Schaffer AA, Burger J, Tadmor Y, Lewinsohn E, Katzir N. 2008. The molecular and biochemical basis for varietal variation in sesquiterpene content in melon (Cucumis melo L.) rinds. Plant Mol Biol 66 (6): 647-661. DOI: 10.1007/s11103-008-9296-6.

Renner SS, Schaefer H, Kocyan A. 2007. Phylogenetics of Cucumis (Cucurbitaceae): Cucumber ( $C$. sativus) belongs in an Asian/Australian clade far from melon (C. melo). BMC Evol Biol 7 (1): 1-11. DOI: 0.1186/1471-2148-7-58.

Robinson RW, Decker-Walters DS. 1997. Cucurbits. Cab International, Wallingford, UK.

Rubatzky VE, Yamaguchi M. 1997. World Vegetables: Principles, Production, and Nutritive Values. Chapman and Hall, New York. 
Ruggieri V, Alexiou KG, Morata J, Argyris J, Pujol M, Yano R, Nonaka S, Ezura H, Latrasse D, Boualem A, Benhamed M, Bendahmane A, Cigliano RA, Sanseverion W, Puigdomenech P, Casacuberta JM, Garcia-Mas J. 2018. An improved assembly and annotation of the melon (Cucumis melo L.) reference genome. Sci Rep 8 (1): 1-9. DOI: 10.1038/s41598-018-26416-2.

Saitou N, Nei M. 1987. The neighbor-joining method: a new method for reconstructing phylogenetic trees. Mol Biol Evol 4 (4): 406-425. DOI: 10.1093/oxfordjournals.molbev.a040454.

Schwab W, Davidovich-Rikanati R, Lewinsohn E. 2008. Biosynthesis of plant-derived flavor compounds. Plant J 54 (2): 712-732. DOI: 10.1111/j.1365-313X.2008.03446.x.

Shalit M, Katzir N, Tadmor Y, Larkov O, Burger Y, Shalekhet F, Lastochkin E, Ravid U, Amar O, Edelstein M, Karchi Z, Lewinsohn E. 2001. Acetyl-CoA: alcohol acetyltransferase activity and aroma formation in ripening melon fruits. J Agric Food Chem 49 (2): 794 799. DOI: $10.1021 / \mathrm{jf} 001075 \mathrm{p}$

Srivathsan A, Meier R. 2012. On the inappropriate use of Kimura-2 Parameter (K2P) divergences in the DNA-barcoding literature. Cladistics 28 (2): 190-194. DOI: 10.1111/j.1096-0031.2011.00370.x.

Stamnes MA, Rutherford SL, Zuker CS. 1992. Cyclophilins: a new family of proteins involved in intracellular folding. Trends Cell Biol 2 (9): 272-276. DOI: 10.1016/0962-8924(92)90200-7.

Van Pelt-Verkuil E, Van Belkum A, Hays JP. 2008. Principles and Technical Aspect of PCR Amplification. Springer Science Business Media, Dordrecht.
Wang P, Heitman J. 2005. The cyclophilins. Genome Biol 6 (7): 1-6. DOI: 10.1186/gb-2005-6-7-226.

Wang Q, Hillwig HL, Wu Y, Peters RJ. 2012. CYP701A8: A rice entkaurene oxidase paralog diverted to more specialized diterpenoid metabolism. Plant Physiol 158 (3): 1418-1425. DOI: 10.1104/pp.111.187518.

Whitaker TW, Bemis WP. 1976. Cucurbits, Cucumis, Citrullus, Cucurbita, Lagenaria (Cucurbitaceae). In: Simmonds NW (ed.) Evolution of Crop Plants. Longrams, New York.

Yang L, Cai K, Huang H, Zhang Y, Zong Y, Wang S, Shi J, Li X, Liao F, Lu M, Guo W. 2019. Comparative analysis of anatomy, gene expression of Vaccinium corymbosum cyclins and cyclin dependent kinases during the flower bud and fruit ontogeny. Sci Hort 251: 252259. DOI: 10.1016/j.scienta.2019.03.028.

Yu XZ, Lu CJ, Tang S, Zhang Q. 2019. Transcriptomic analysis of cytochrome $\mathrm{P} 450$ genes and pathways involved in chromium toxicity in Oryza sativa. Ecotoxicology 29 (5): 503-513. DOI: 10.1007/s10646-019-02046-w.

Zheng Y, Wu S, Bai Y, Sun H, Jiao C, Guo S, Zhao K, Blanca J, Zhang Z, Huang S, Xu Y, Weng Y, Mazourek M, Reddy UK, Ando K, McCreight JD, Schaffer AA, Burger J, Tadmor Y, Katzir N, Tang X, Liu Y, Giovannoni JJ, Ling KS, Wechter WP, Levi A, Garcia-Mas J, Grumet R, Fei Z. 2019. Cucurbit Genomics Database (CuGenDB): a central portal for comparative and functional genomics of cucurbit crops. Nucleic Acids Res 47 (D1): D1128-D1136. DOI: 10.1093/nar/gky944. 